\title{
Penerapan Teknologi Tepat Guna Untuk Pengelolaan Sampah KRL Berani Asri Duta Mekar Asri Cileungsi Bogor
}

\author{
Prayudi $^{1}$; Arief Suardi ${ }^{2}$; Roswati Nurhasanah ${ }^{3}$ Hendri $^{4}$ \\ 1, 2, 3, 4 Program Studi Teknik Mesin Fakultas Teknologi dan Bisnis Energi \\ Institut Teknologi PLN \\ ${ }^{1}$ prayudi@itpln.ac.id \\ 2 arief.suardi@itpln.ac.id \\ ${ }^{3}$ roswati@itpln.ac.id \\ ${ }^{4}$ hendri@itpln.ac.id
}

\begin{abstract}
Green Village (KRL) is one of the programs to realize Bogor Green and Clean Regency. KRL Berani Asri RW 15 Cileungsi Kidul was formed to carry out the production, management and utilization independently. KRL Berani Asri has several problems such as environmentally friendly awareness, not yet optimal waste management, the economic potential of organic and non-organic waste. P2M Mechanical Engineering Study Program IT PLN aims to provide alternative solutions so that KRL Berani Asri is independent in waste management. The method of implementation is socialization, training on waste management, composting, and making plastic chopper machines. The results of the P2M are $67.8 \%$ of resident have knowledge about waste management, $61.7 \%$ have good waste management behavior, and $53.8 \%$ of residents say that KRL Berani Asri does not yet have waste management infrastructure. The use of appropriate technology has an impact on increasing compost production from 50 bags to 200 bags per week, and the production of plastic that has been sold from $10 \mathrm{~kg}$ to $100 \mathrm{~kg}$ per week.
\end{abstract}

Keywords: socialization, waste management, KRL Berani Asri, Cileungsi Kidul

\begin{abstract}
ABSTRAK
Kampung Ramah Lingkungan (KRL) adalah salah satu program untuk mewujudkan Bogor Kabupatenku Green and Clean. KRL Berani Asri RW 15 Cileungsi Kidul dibentuk untuk melakukan eduksi, pengelolaan dan pemanfaatan secara mandiri. Permasalahannya adalah kesadaran masyarakat akan kampung ramah lingkungan, belum optimalnya pengelolaan sampah, potensi ekonomi sampah organik dan nonorganic. P2M Prodi Teknik Mesin IT PLN bertujuan untuk memberikan solusi agar KRL Berani Asri mandiri dalam pengelolaan sampah. Metode pelaksanaannya sosialisasi, pelatihan pengelolaan sampah, pembuatan kompos, serta pembuatan mesin pencacah plastik. Hasil dari P2M adalah 67,8 \% warga memiliki pengetahuan tentang pengelolaan sampah, 61,7\% memiliki perilaku pengelolaan sampah yang baik, dan 53,8\% warga mengatakan bahwa KRL Berani Asri belum memiliki prasarana pengelolaan sampah. Penggunaan teknologi tepat berdampak pada peningkatan produksi kompos dari 50 kantong menjadi 200 kantong per minggu, dan produksi palstik yang berhasil dijual dari $10 \mathrm{~kg}$ menjadi $100 \mathrm{~kg}$ per minggu.
\end{abstract}

Kata kunci: sosialisasi, pengelolaan sampah, KRL Berani Asri, Cileungsi Kidul 


\section{PENDAHULUAN}

Permasalahan pengelolaan sampah merupakan masalah bersama. Pengelolaan sampah adalah kegiatan yang sistematis, menyeluruh dan berkesinambungan yang meliputi kegiatan penguraian dan penanganan sampah. Pengelolaan sampah merupakan kegiatan pemisahan komponen sampah dan pemadatan untuk penyimpanan dan pengangkutan. Sesuai UU No 18 Tahun 2008 Pasal 4, pengelolaan sampah pada dasarnya bertujuan untuk meningkatkan kesehatan masyarakat dan kualitas lingkungan hidup [1]. Sampah menurunkan kualitas lingkungan hidup, estetika, dan pembuangan sampah ke saluran air mengakibatkan banjir dan pencemaran lingkungan [2].

Mengacu peraturan Bupati Kabupaten Bogor No. 2 Tahun 2014, bahwa pengelolaan sampah di Kabupaten Bogor menerapkan konsep 3R, yaitu reduce, reuse dan recycle. Konsep 3R ini mendorong masyarakat memanfaatkan sampah yang memiliki nilai ekonomis. Implementasi UU No. 2 Tahun 2008, Pemda Kabupaten Bogor menerbitkan Perda No 6 Tahun 2016 yang mengatur tentang Perlindungan dan Pengelolaan Lingkungan Hidup, Pemda Kabupaten Bogor mencanangkan Bogor Kabupatenku Green and Clean. Salah satu programnya adalah Kampung Ramah Lingkungan (KRL). Menurut definisinya KRL adalah perilaku kehidupan sehari-hari yang efisien dalam memanfatkan sumber daya alam [3]. KRL adalah suatu lokasi yang masyarakatnya melakukan upaya atau tindakan nyata pengelolaan lingkungan hijau secara teratur dan berkesinambungan. Tujuan KRL adalah adalah mendorong Pemda, dunia usaha, dan masyarakat memahami permasalahan lingkungan dan dampaknya. Cakupan program PKL antara lain pengendalian kekeringan, pengelolaan sampah, pembuatan biopori, penyediaan bank sampah, dan kreasi sampah daur ulang yang bernilai ekonomis. Dari kegiatan KRL ini adalah terciptanya Kawasan KRL Pratama dan KRL Madya [4].

Desa Cileungsi Kidul merupakan salah satu desa di Kecamatan Cileungsi Kabupaten Bogor dipimpin oleh Edy Supriatman, SIP (Alm) sebagai Kepala Desa. Desa Cileungsi Kidul terdiri atas 7 (tujuh) Dusun yang dipimpin oleh seorang Kadus, dan terdapat 20 (dua puluh) Rukun Warga (RW). RW 15 Duta Mekar Asri merupakan salah satu RW di lingkungan desa Cileungsi Kidul yang merupakan desa mitra kegiatan P2M. Desa Cileungsi Kidul berjarak 49,2 km dari kampus IT PLN Jakarta. Dalam rangka mewujudkan Bogor Kabupatenku Green and Clean, melalui program KRL, Kepala Desa Cileungsi Kidul menerbitkan Keputusan No. 147/14/Kpts/IV/2018 tentang Bank Sampah, dan Keputusan No. 147/158/Kpts/III/2018 tentang Pembentukan KRL Berani Asri. Dalam melaksanakan program kerja KRL Berani Asri telah mendapatkan bantuan dari berbagai perusahaan dalam rangka CSR antara lain Astra Auto Part Regional Bogor, PT. PLN UP 3 Gunung Putri, PT. PLN UPJ Cileungsi, dan Dinas Lingkungan Hidup Kabupaten Bogor.

Berdasarkan hasil survey pendahuluan, kegiatan program KRL Berani Asri masih belum optimal antara lain (1) pengelolaan sampah belum menggunakan pendekatan 3R, (2) produksi kompos masih manual dan kapasitas produksinya rendah seperti terlihat pada Gambar 2, (3) penimbangan dan pemilahan sampah non organik, (4) kreasi daur ulang sampah belum optimal. Pada sisi lain, luasnya wilayah KRL dan potensi untuk dapat dikembangkan, dirasakan perlu dukungan dan mitra kerja untuk mengoptimalkan sumber daya masyarakat sehingga pogram KRL dapat dilaksanakan dengan baik. Adapun potensi pengembangan wilayah KRL Berani terlihat pada Gambar 1. 


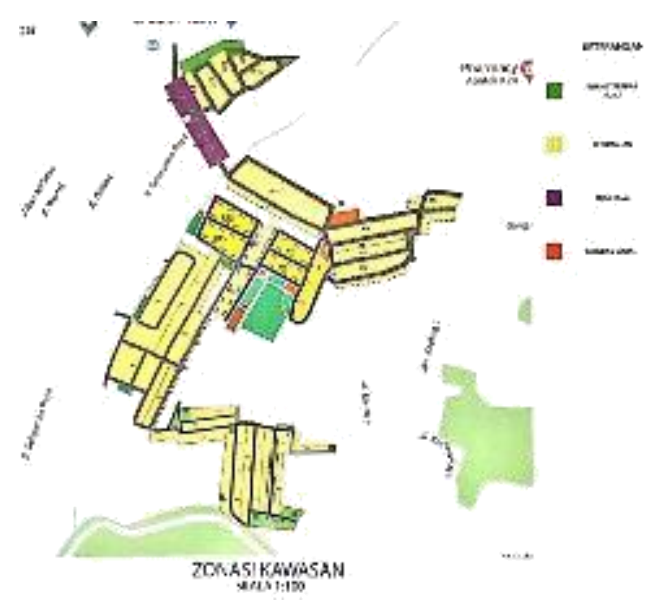

Gambar 1. Potensi KRL Berani Asri

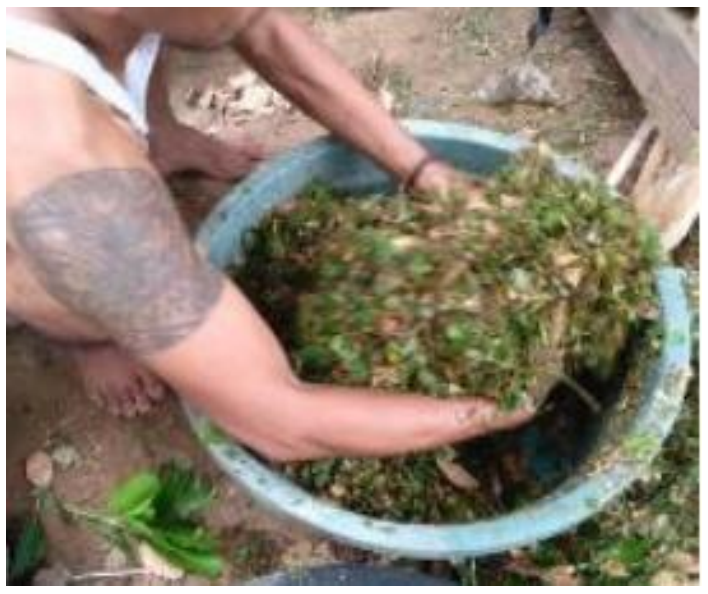

Gambar 2. Proses Pembuatan Kompos

Menurut berbagai hasil kajian bahwa terdapat 5 (lima) hal pokok yang perlu diperhatikan dalam pengelolaan sampah yakni aspek kelembagaan, aspek pembiayaan, aspek pengaturan (dasar hukum), aspek peran sert masyarakat, dan aspek operasional [5]. Keikutsertaan masyarakat dalam program KRL ini dapat mengurangi beban lingkungan dalam pengelolaan sampah, disamping itu masyakarat akan mendapat keuntungan ekonomis dengan membuat kreasi-kreasi daur ulang sampah yang bernilai ekonomis, manfaat lainnya adalah masyarakat dapat membuat pupuk organic [6].

Berdasarkan analisis situasi dan diskusi dengan mitra beberapa permasalahan yang dapat dipetakan adalah (1) Pemahaman konsep KRL belum sepenuhnya dipahami oleh seluruh lapisan masyarakat di RW 15, (2) masih tercampurnya sampah rumah tangga kering dan basah, (3) pengelolaan sampah belum tertata dengan baik, (4) pemanfaatan sumber daya ekonomi daur ulang sampah belum optimal (5) pembuatan kompos dari kegiatan bank sampah belum optimal. Permasalahan prioritas yang harus segera diselesaikan adalah (1) sosialisasi pengelolaan sampah terpadu berbasis masyarakat, dan (2) optimalisasi potensi sumber daya ekonomi untuk pamanfaataan sampah.

Menurut SNI 3242:2008 tentang pengelolaan sampah di pemukinan terdiri atas system perwadahan, system pengumpulan, system pemindahan, system pengangkutan, system pembuangan akhir, dan system pengelolaan sampah. Dalam aspek ini, masyarakat harus diedukasi bahwa pengelolaan sampah harus menggunakan prinsip 3R, dimulai dari pentingnya pemilahan sampah, pembentukan bank sampah, composting dan pemanfaatan nilai ekonomis daur ulang sampah [7]. Terdapat beberapa metode yang dapat digunakan untuk menyelesaikan permasalahan sampah, seperti bank sampah [6], melibatkan peran serta masyarakat dalam pengelolaan sampah [1], dimana peran serta masyarakat dalam pengelolaan sampah, khususnya sampah rumah tangga dapat menurunkan 33\% produksi sampah rumah tangga, khususnya sampah anorganik [8]. Pengelolaan bank sampah kedepannya diperlukan adanya teknologi tepat guna yang memiliki nilai ekonomis yang tinggi [5].

Sosialisasi merupakan proses penamaan dan proses transfer kebiasaan, atau nilai dan aturan dari suatu generasi atau suatu kelompok masyarakat. Sosialisasi berupa penyampaian informasi dalam bentuk komunikasi dengan cara penyampaian gagasan, dan ketrampilan-ketrampilan. Sosialisasi adalah suatu usaha non formal untuk mengajak orang sadar dan mau melakukan ide-ide baru [9]. Mengubah perilaku membuang sampah sembarangan tidak bisa diubah secara sembarangan, hal ini terkait perilaku orang dan budaya. Melalui sosialisasi berkesinambungan mengenai dampak yang diakibatkan dari perilaku membuang sampah sembarangan dapat memunculkan niat dan 
kesadaran pribadi untuk tidak membuang sampah sembarangan. Kegiatan sosialisasi dapat dilakukan dengan cara metode ceramah, simulasi, demontrasi serta diskusi. Kegiatan sosialisasi harus mampu meningkatkan pengetahuan dan kesadaran public terhadap peningkatan kualitas lingkungan dan pemanfaatan limbah sampah bagi perbaikan nilai ekonomis [10].

Berdasarkan komposisi kimianya sampah dapat dibedakan menjadi sampah organic dan sampah anorganik, dimana $80 \%$ merupakan sampak organic, dan diperkirakan $78 \%$ dapat digunakan kembali. Kompos adalah pupuk alami (organic) yang terbuat dari bahan hijau-hijauan dan tumbuhan. Pada dasarnya sampah dapat dijadikan kompos [11]. Penggunaan teknologi tepat guna sudah diterapkan untuk pengelolaan sampah anorganik dan pembuatan composting. Teknologi sederhana pengelolaan sampah plastic jenis PP, PET, dan PE dapat diolah menjadi bahan bakar, Plastik dengan type PP menghasilkan minyak paling banyak. Berdasarkan kandungan atomnya plastic jenis PP dan PE, minyak yang dihasilkan mendekati bensin dan minyak tanah [12]. Daur ulang proses pengelolaan sampah plastic dipilih, selanjutnya dimasukan kedalam mesin pencacah (pirolisis), selanjutnya dipanaskan, Hasil inovasi ini adalah sampah menjadi bahan bakar minyak [13]. Penggunaan teknologi pemanfaaatan biogas dari sampah, pengelolaan lumpur digester menjadi pupuk organic dan pupuk cair [14]. Dari berbagai hasil penelitian diatas setidaknya kegiatan daur ulang plastic memiliki dua nilai positip yaitu (1) mengurangi pencemaran limbah plastic di lingkungan, dan (2) menciptakan lapangan kerja [15].

\section{METODE PELAKSANAAN}

Sesuai dengan rencana program yang disepakati untuk menyelesaikan permasalahan, dikerjakan dalam dua aspek yakni (1) Aspek sosialisasi dan pelatihan (2) Aspek proses produksi, khususnya proses produksi kompos dan pengelolaan sampah plastik. Aspek sosialisasi dan pelatihan ditujukan untuk meningkatkan pengetahuan pengelolaan sampah bagi warga KRL Berani Asri. Aspek proses produksi lebih ditujukan pemanfaatan teknologi tepat guna untuk meningkatkan kapasitas produksi kompos dan pemanfaatan limbah plastik. Untuk menjalankan program tersebut, secara garis besar metode pelaksanaannya adalah sebagai berikut.

(1) Tahap awal Persiapan. Tim P2M Prodi Teknik Mesin bersama dengan mitra KRL Berani Asri menyusun rencana kerja yang dituangkan dalam bentuk proposal. Mitra kerja mempersiapkan administrasi di tingkat Desa Cileungsi Kidul, dan tim P2M melakukan finalisasi penyusunan proposal. Pada tahap awal ini tim P2M juga melakukan survey pendahuluan untuk mengetahui potensi dan permasalahan yang ada di desa mitra KRL Berani Asri Duta RW 15 Mekar Asri Desa Ciluengsi Kidul Bogor.

(2) Tahap Kedua adalah sosialisasi dan pelatihan. Pada tahap ini mitra kerja KRL Berani Asri RW 15 Cileungsi Kidul dan tim akan bekerja sama dengan Dinas Lingkungan Hidup untuk membantu melaksanakan sosialisasi pengelolaan sampah. Sedangkan tim P2M dan KRL akan memberikan pelatihan kepada petugas yang nantinya akan bertugas untuk membuat pupuk dan memproduksi kompos

(3) Tahap pelaksanaan peningkatan proses produksi. Pada tahap ini tim P2M akan membantu mendesain dan membuat mesin produksi untuk pembuatan kompos dan mesin pencacah plastik

(4) Tahap evaluasi dan monitoring, dan rancangan tindak lanjut. Pada tahap ini tim P2M menggunakan instrumen kuisioner untuk mengetahui dampak hasil sosialisasi dan pelatihan, sedangkan proses produksi tim P2M akan menggunakan data produksi kompos per minggu dan pencacahan serta penjualan limbah plastic. 
(5) Tahap penyusunan laporan dan desiminasi hasil kegiatan. Bentuk output kegiatan dari kegiatan ini adalah adanya deseminasi hasil kegiatan P2M yang berupa publikasi karya ilmiah dalam bentuk paper yang dipublikasikan seminar P2M, video kegiatan yang diunggah di media sosial Youtube minimal 5 (lima) menit, dan berita yang dipublikasikan pada media elektronik.

\section{HASIL DAN PEMBAHASAN}

\subsection{Lokasi P2M}

Lokasi kegiatan P2M Prodi Teknik Mesin Fakultas Teknologi dan Bisnis Energi IT PLN pada tahun akademik 2019/2020 adalah KRL Berani Asri RW 15 Desa Cileungsi Kidul Kecamatan Cileungsi Kabupaten Bogor, yang berjarak 42,5 km dari kampus Institut Teknologi PLN. Adapun denah dan tanda bukti spanduk pelaksanaan program P2M Podi Teknik Mesin FTBE IT PLN adalah sebagai berikut.

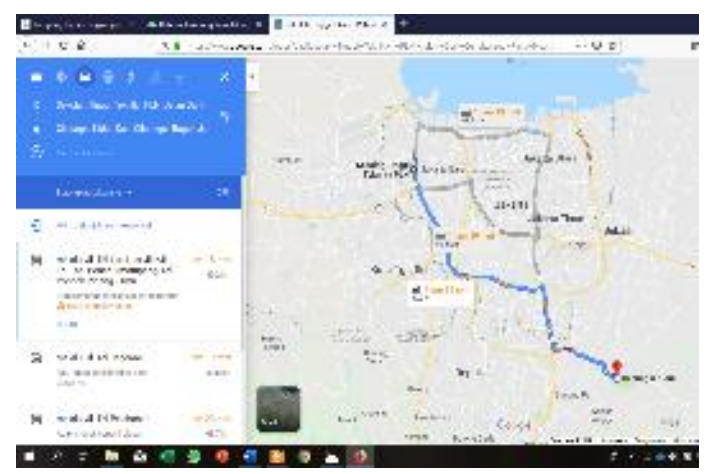

Gambar 3. Denah Lokasi P2M

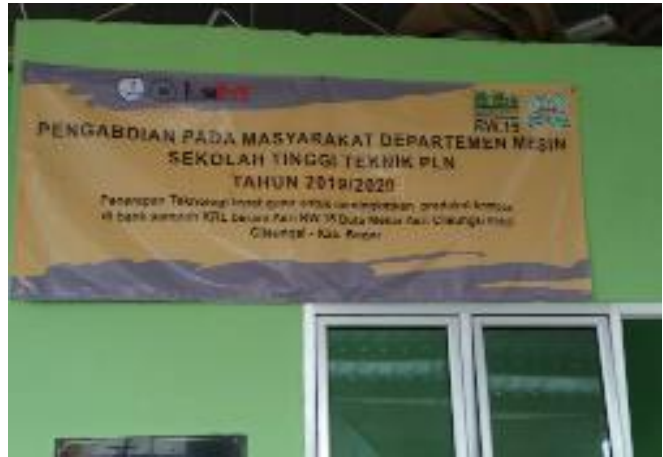

Gambar 4. Lokasi P2M KRL berani Asri

\subsection{Tim Pelaksana P2M}

Tim pelaksana P2M terdiri atas tim dari Prodi Teknik Mesin terdiri atas 4 (orang) yang dipimpin oleh Drs. Prayudi, MM., MT dengan anggota Arief Nur Chairat, ST, MT., Roswati Nurhasanah, ST, MT., dan Hendri, ST, MT (Gambar 5). Tim juga dibantu oleh 2 (dua) orang mahasiswa yakni Helmy Darmawan NIM 2017-12-076 dan Bima Alif NIM 2017-12-068. Sedangkan dari pihak mitra KRL berani Asri dipimpin oleh Bapak Purlan dengan penasehat Kepala Desa Cileungsi Kidul bapak Edy Supriatman, SIP. Gambar 6.

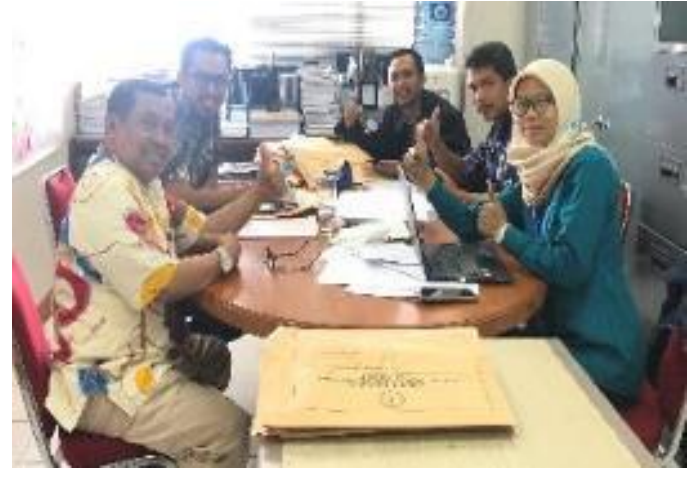

Gambar 5. Tim P2M Proti TM FTBE

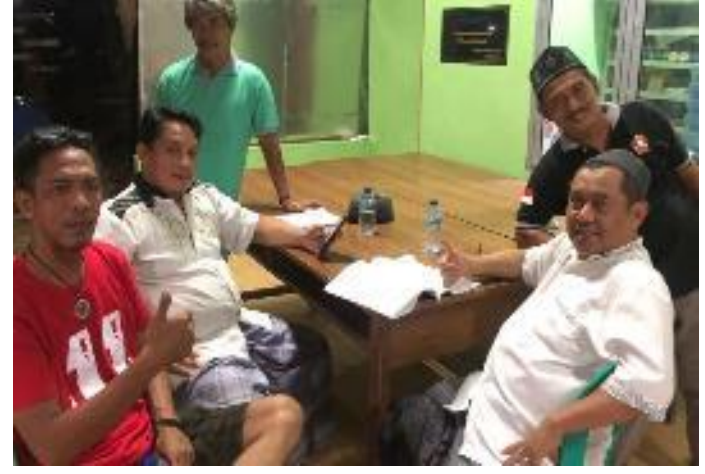

Gambar 6. Mitra KRL Persiapan Sosialisasi 


\subsection{Pelaksanaan Sosialisasi dan Pelatihan}

Sosialisasi dilaksanakan pada tanggal 18 Januari 2020. Sosialisasi diikuti oleh warga RW 15 Desa Cileungsi Kidul. Dokumentasi sosialisasi pada Gambar 8, 9 dan Gambar 10.

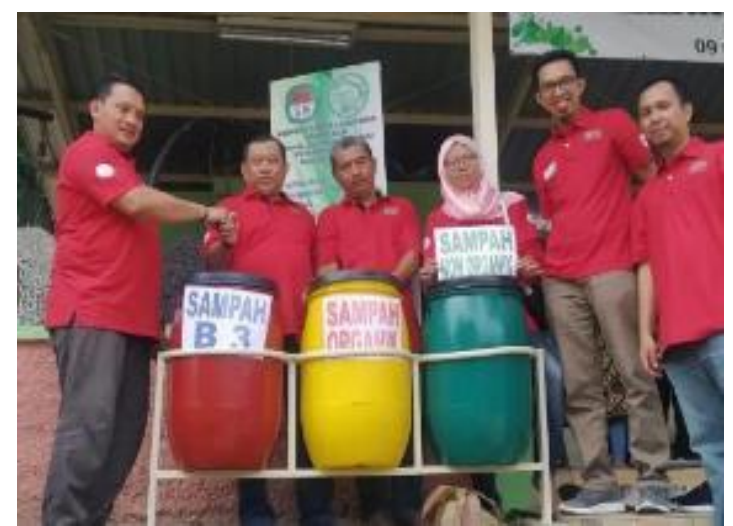

Gambar 7. Penyerahan Alat Peraga Sosialisasi

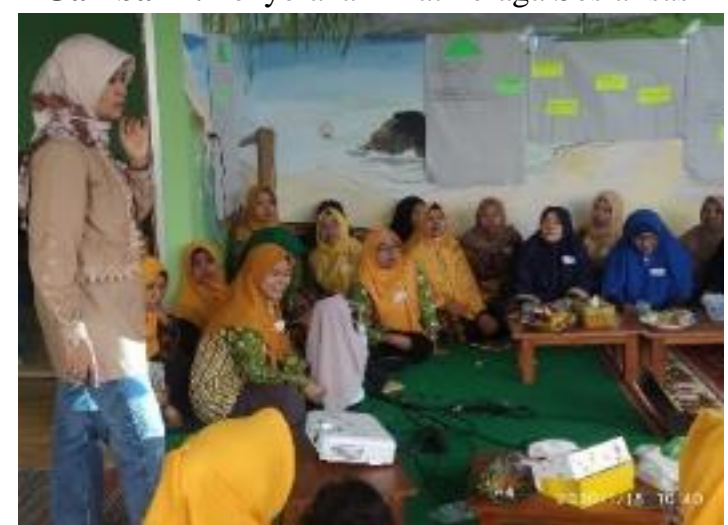

Gambar 9. Sosialisasi dari DLH

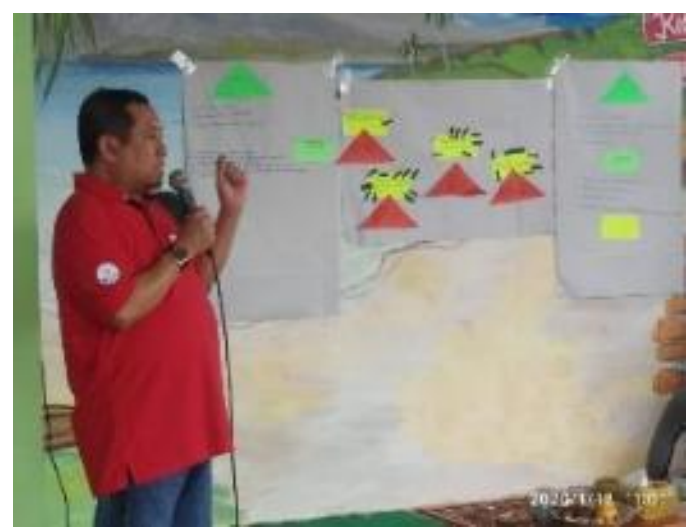

Gambar 8. Penjelesan Peragaan Sosialisasi

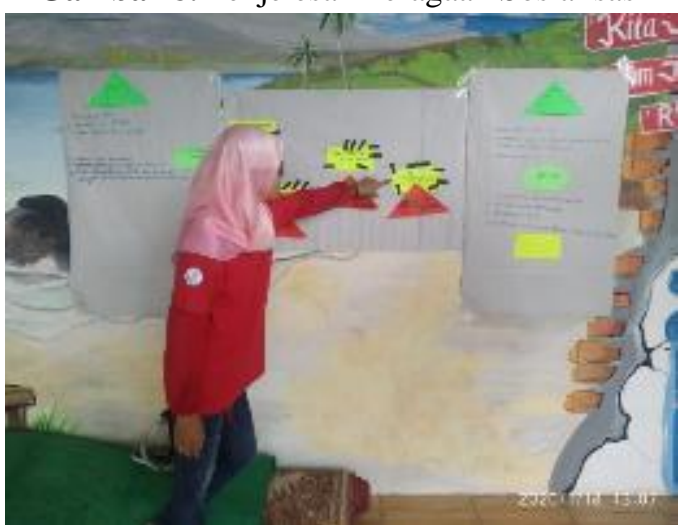

Gambar 10. Praktek Peragaan Simulasi

Sebelum sosialisasi dilaksanakan rapat pendahuluan tim P2M dan Mitra Kerja. Sosialisi terlaksana berkat kerjasama dengan mitra kerja KRL Berani Asri, Dinas Lingkungan Hidup Kabupaten Bogor. Pemberi materi sosialisasi ada ibu Peni dari IPB Bogor. Sedangkan kegiatan pelatihan pembuatan kompos juga dilaksanakan pada tanggal 18 Januari 2020, dan 13 Maret 2020. Tim P2M bertugas memberikan masukan, dengan mempraktekan secara langsung pembuatan kompos. Dokumentasi kegiatan terlihat pada Gambar11, berikut ini. 


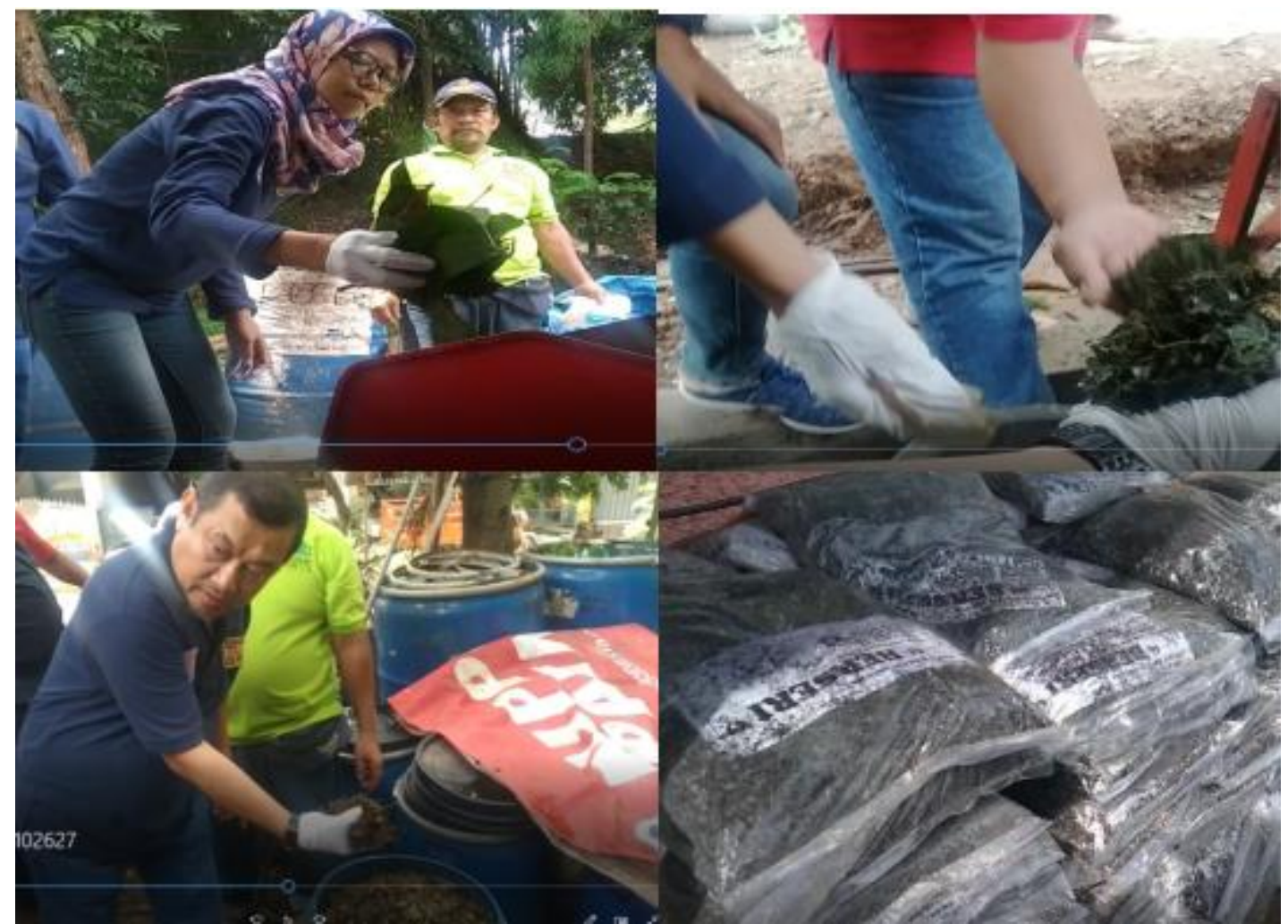

Gambar 11. Proses Pembuatan Kompos

\subsection{Pelaksanaan Pemanfaatan Teknologi Tepat Guna}

Sebagai bentuk implemantasi dari kegiatan proses produksi pembuatan kompos dan pengelolaan limbah plastic, Tim P2M Prodi Teknik menyumbang membantu dan membuat mesin pencacah plastic. Berikut ini adalah dokumentasi pembuatan mesin pencacah plastic.

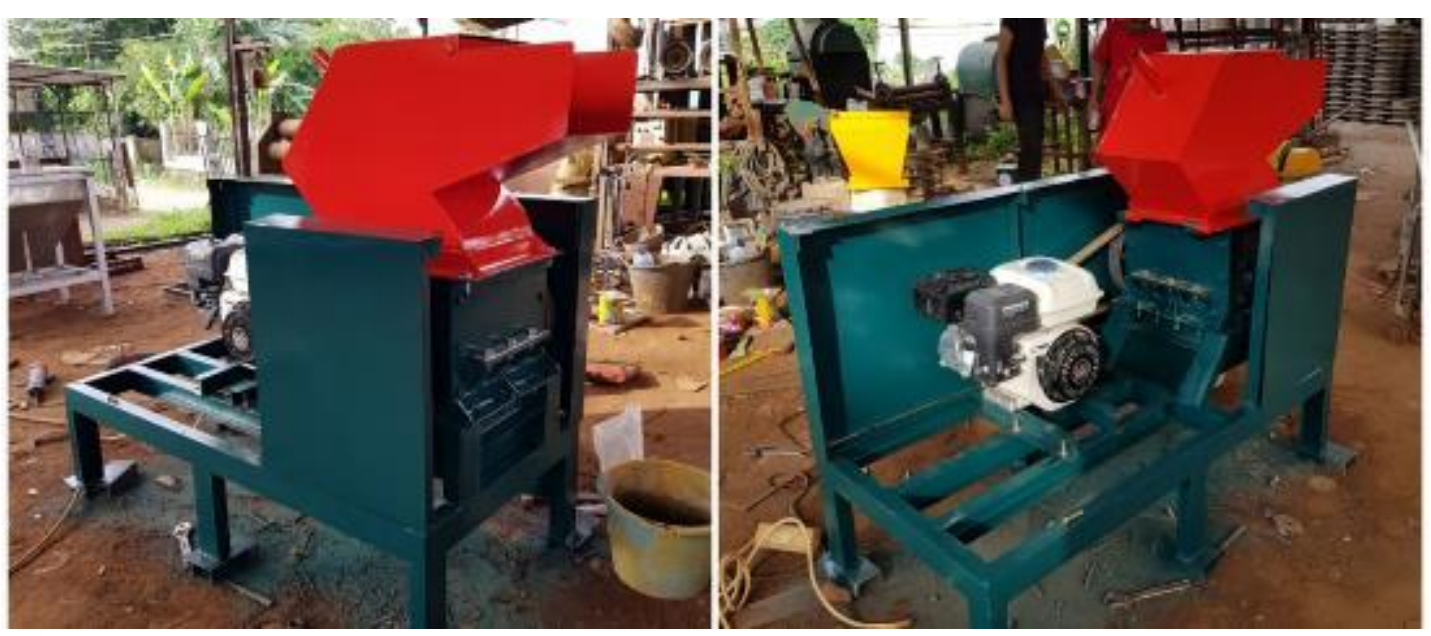

Gambar 12. Proses Pembuatan Mesin Pencacah Plastik

Sedangkan berikut ini adalah proses serah terima mesin bantuan dari P2M Teknik Mesin yang disajikan pada Gambar 13 dan Gambar 14. Pada acara kegiatan penyerahan mesin produksi, dan praktek uji coba mesin proses produksi ini disaksikan oleh Kepala Desa Cileungsi Kidul dan anggota DPRD dari Ketua Komisi III Kabupaten Bogor 


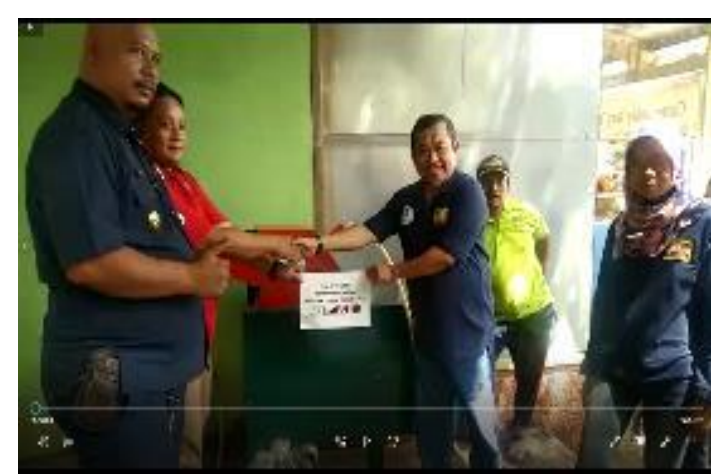

Gambar 13. Serah Terima Mesin Pencacah

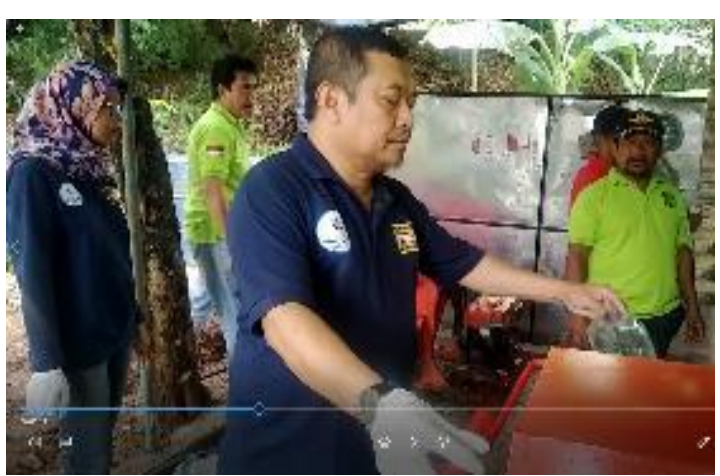

Gambar 14. Uji Coba Mesin Pencacah

\subsection{Hasil Umpan Balik Pelatihan}

Untuk mengetahui efektivitas sosialisasi dan pelatihan pengelolaan sampah, sertama manfaatnya, Tim P2M Prodi Teknik Mesin IT PLN menggunakan instrumen kusioner. Dalam kuisioner informasi yang akan digali terkait presepsi warga tentang pengetahuan, perilaku dan sikap serta prasarana pengelolaan sampah di Kampung Ramah Lingkungan Berani Asri RW 15 Duta Mekar Asri Cileungsi Kidul. Kuisioner dibagikan sesudah mengikuti sosialisasi, hasilnya sebagai berikut.

\subsubsection{Presepsi Pengetahuan Pengelolaan Sampah}

Hasil kuisioner untuk mengetahui presepsi warga KRL berani Asri Duta Mekar Asri RW 15 Duta Mekar Asri tentang pengetahuannya pengalolaan sampah disajikan pada Gambar 15. Terdapat 9 butir pertanyaan untuk mengetahui presepsi warga tentang pengelolaan sampah dari pertanyaan apah saudara mengetahui nilai ekonomi sampah, sampai dengan apakah saudara mengetahui jenisjenis sampah, hasilnya disajikan pada Gambar 15.

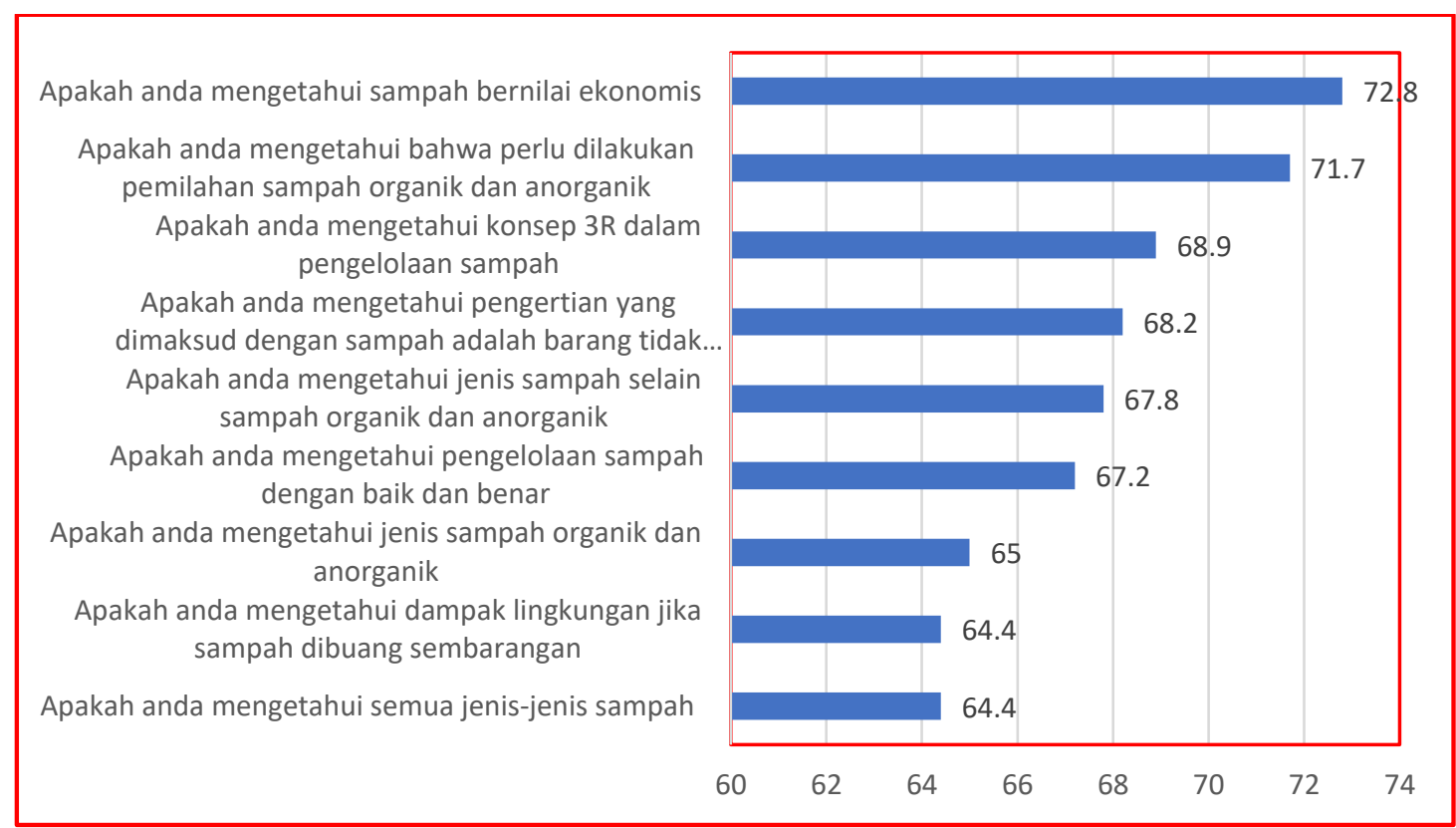

Gambar 15. Profil Skor Presepsi Pengetahuan

Berdasarkan Gambar 15, warga KRL Berani Asri RW 15 Duta Mekar Asri mempresepsikan bahwa dirinya, telah memiliki pengetahuan yang cukup tentang pengelolaan sampah yakni $67,8 \%$. 
Modal pengetahuan yang cukup besar merupakan salah satu keuntungan yang dapat dioptimalkan oleh pengurus KRL Berani Asri untuk mengoptimalkan potensi warga dalam mengelola sampah serta memanfaatkan potensi ekonominya.

Dari Gambar 15, skor terendah adalah apakah anda mengetahui jenis-jenis sampah skornya 64,4 artinya bahwa $64,4 \%$ warga mempresepsikan dirinya telah memiliki pengetahuan yang cukup tentang sampah. Sedangkan skor penting adalah apakah anda mengetahui sampah bernilai ekonomis dengan skor 72,8 \%. Hal ini wajar karena warga KRL Berani Asri adalah warga perumahan yang memiliki pengetahuan yang cukup tentang pengelolaan sampah.

\subsubsection{Presepsi Sikap dan Perilaku Pengelolaan Sampah}

Untuk mengetahui presepsi sikap dan perilaku warga terhadap pengelolaan sampah di KRL Berani Asri RW 15 Duta Mekar Asri, Tim P2M Prodi S1 Teknik Mesin menyampaikan 8 (delapan) butir pertanyaan yang terkait dengan sikap dan perilaku warga terhadap pengelolaan sampah. Pertanyaan ini mulai dari sikap paling dasar untuk membuang sampah pada tempatnya, sampai dengan kerelaan untuk membuang sampah yang ada di jalan. Hasilnya presepsi warga terkait dengan sikap dan perilaku disajikan pada gambar berikut ini,

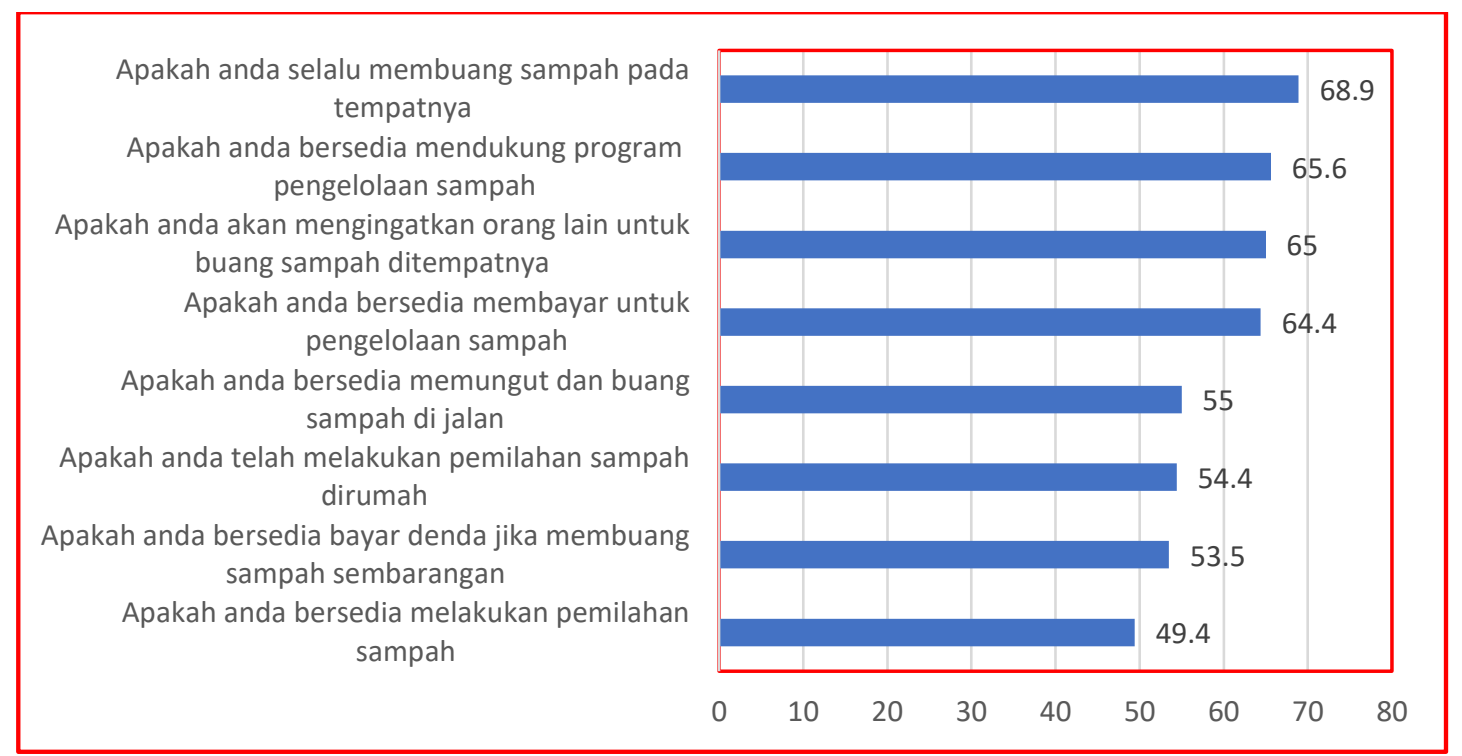

Gambar 16. Profil Skor Presepsi Sikap dan Perilaku

Skor terendah adalah bahwa warga belum melakukan pemilahan sampah di rumah, artinya adalah warga di KRL Berani Asri belum mempraktekkan pengetahuan yang dimilikinya di rumah, walaupun mereka bersedia melakukan pemilahan sampah di rumah. Hal ini merupakan suatu fenomena yang bertolak belakang antara pengetahuan dengan sikap perilaku. Berdasarkan data pada Gambar 16, terlihat bahwa sebagian warga masih belum memiliki kesadaran untuk memilah sampah dari rumah masing-masing, dengan skor 49,4\%. Hal ini disebabkan karena kebiasaan selama ini dalam membuang sampah, karena diperlukan minimal 3 buah tong sampah untuk menampung sampah. Jelas hal ini akan menimbulkan biaya lebih dan lahan depan rumah yang cukup. Sedangkan kondisi lahan belum memungkinkan. Oleh karena itu perlu sosialisasi yang berkesimbungan agar, kegiatan pemilahan sampah dari rumah masing-masing dapat terlaksana dengan baik. 


\subsubsection{Presepsi Prasarana Pengelolaan Sampah}

Pada bagian ketiga kuisioner, tim P2M menanyakan tentang presepsi warga tentang sarana dan prasarana pengelolaan sampah yang ada di KRL Berani Asri RW 15. Terdapat 7 (tujuh) butir pertanyaan mulai dari keberadaan bank sampah, tersedia bak sampai di setiap falitas umum, tempat sampah di lengkapi dengan tutup, sampai dengan prasarana pengelolaan sampah di KRL Berani Asri RW 15 Duta Mekar Asri. Hasil pengolahan data presepsi warga tentang prasarana pengelolaan sampah, hasilnya dinyatakan pada Gambar 17.

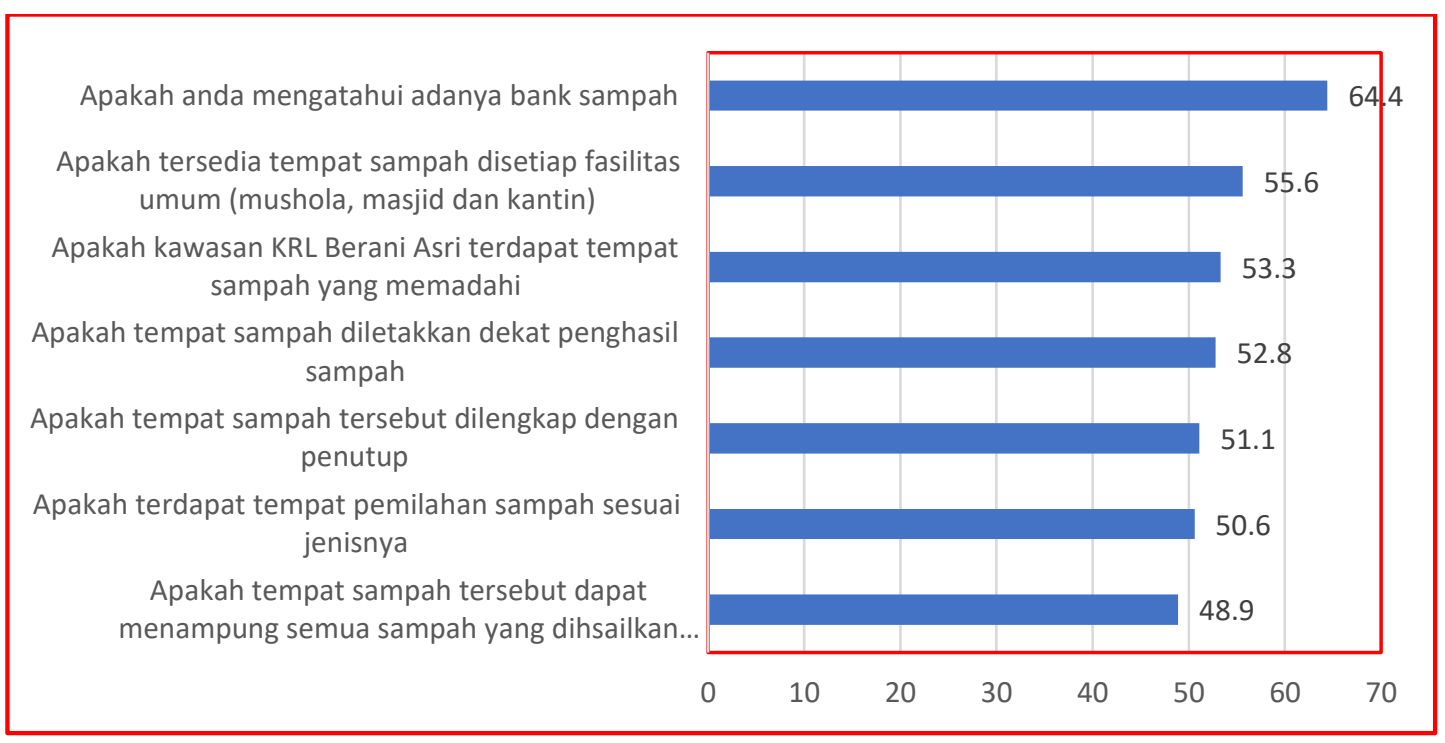

Gambar 17. Profil Skor Presepsi Prasarana Penelolaan Sampah

Dari skor pada Gambar 17, bahwa sebagian besar warga sudah mengetahui bahwa KRL Berani Asri sudah memiliki Bank Sampah. Namun demikian, keberadaan bank sampah bertolak belakang dengan presepsi warga tentang prasarana pengelolaan sampah yang lain. Skor rata-rata profil presepsi warga tentang prasarana adalah 53,8\%, artinya sebagian besar warga memiliki presepsi bahwa KRL Berani Asri belum memiliki prasarana yang baik dan memadahi dalam pengelolaan sampah. Oleh karena itu, kedepannya perlu dijadikan prioritas bahwa sarana dan prasarana dalam pengelolaan sampah factor ini yang perlu mendapatkan perhatian khusus.

\subsection{Hasil Evaluasi Penggunaan Teknologi}

Hasil dari penggunaan teknologi tepat guna dapat ditinjau dari rata-rata kenaikan produksi. Sebelum menggunakan teknologi mesin pencacah daun, kapasitas produksi pembatan kompos adalah 50 kantong per minggu, setalah menggunakan mesin pencacah daun kapasitas produksi meningkat 150 kantong per minggu, atau peningkatan produksi $150 \%$. Sedangkan penggunaan mesin pencacah plastik ini, sebelum menggunakan mesin ini dalam minggu hanya bisa menjual palstik dlam bentuk botol $10 \mathrm{~kg}$ per minggu. Namun setelah menggunakan mesin in dapat menjual platik bernilai ekonomi sebanyak $50 \mathrm{~kg}$ per minggu.

\subsection{Rancangan Tindak Lanjut}

Dari hasil evaluasi penggunaan teknologi untuk proses produksi ini adalah kelanjutan bahan baku dan masalah pemasaran khususnya untuk kompos. Oleh karena itu di masa mendatang perlu adanya upaya yang sistematis untuk pemasaran hasil produksi kompos yang dihasilkan KRL Berani Asri. Penanganan limbah plastik perlu dikembangkan, misalnya mengembangkan teknologi tepat guna untuk bahan bakar cair yang berasal dari limbah plastik. 


\section{KESIMPULAN DAN SARAN}

\subsection{Kesimpulan}

Berdasarkan pada analisis dan hasil dapat disimpulan bahwa :

a. Sosialisasi dan pelatihan yang dijalankan telah berhasil meningkatkan presepsi pengetahuan tentang pengelolaan sampah.

b. Perlu adanya sosialisasi yang berkelanjutan untuk pengelolaan sampah, agar wwarga memiliki presepsi yang sama tentang penggunaan prinsip 3R dalam pengelolaan sampah.

c. Perlu adanya peningkatkan prasaran pengelolaan sampah di KRL Berani Asri

d. Penggunaan teknologi tepat guna dapat meningkatkan produksi kompos, dan peningkaan volume penjualan limbah plastic

\subsection{Saran}

Dari hasil analisis dan umpan balik warga bahwa sarana dan prasarana pengelolaan limbah, serta penanganan limbah plastik perlu ditingkatkan. Oleh kerena itu KRL Berani Asri dapat ditingkatkan sebagai Desa Binaan IT PLN dalam pengembangan energi baru dan terbarukan bersumber dari sampah.

\section{UCAPAN TERIMA KASIH}

Program P2M Prodi Teknik Mesin ini terlaksana berkat dukungan pendanaan dari program Hibah Internal P2M untuk tahun akademik 2019/2020 sesuai dengan SK Ketua STT PLN No. 0422.SK/2/A0/2019 tanggal 20 Desember 2019. Oleh karena itu Tim P2M Prodi Teknik Mesin mengucapkan terima kasih kepada ;

- Prof. Dr. Iwa Garniwa Mulyana K, MT selaku Rektor Institut Teknologi PLN yang telah memberikan dukungan persetujuan pendaaan program P2M ini

- Drs. Prayudi, MM. MT selaku Dekan Fakultas Teknologi dan Bisnis Energi yang telah membantu dan memfasilitasi kegiatan P2M ini.

- Indrianto, ST, M. Kom selaku Kepala LPPM Institut Teknologi PLN yang telah membantu terlaksana program $\mathrm{P} 2 \mathrm{M}$ ini.

\section{DAFTAR PUSTAKA}

[1] A. Setiadi, "Studi Pengelolaan Sampah Berbasis Komunitas pada Kawasan Permukiman Perkotaan di Yogyakarta," Wilayah dan Lingkungan, vol. 3, no. 1, pp. 27-38, 2015.

[2] S. A. Mulasari, A. H. Husodo and N. Muhadjir, "Kebijakan Pemerintah dalam Pengelolaan Sampah Domestik," Kesehatan Masyarakat Nasional, vol. 8, no. 8, pp. 404-410, 2014.

[3] A. D. Septiani and N. Yuliastuti, "Perwujudan Kelurahan Ramah Lingkungan (Studi Kasus : Kelurahan Krapyak Kota Semarang)," Pengembangan Kota, vol. 3, no. 2, pp. 120-127, 2015.

[4] K. B. Dinas LH, "Definisi Kampung Ramah Lingkungan," Dinas Lingkungan Hidup, Kabupaten Bogor, 2015.

[5] A. S. Suryani, "Peran Bank Sampah Dalam Efektivitas Pengeloaan Sampah (Studi Kasus Bank Sampah Malang)," Aspirasi, vol. 5, no. 1, pp. 71-84, 2014.

[6] N. M. Ratiabriani and I. B. P. Purbadharmaja, "Partisipasi Masyarakat dalam Program Bank Sampah," Ekonomi Kuantitatif Terapan, vol. 9, no. 1, pp. 53-58, 2016.

[7] V. Yogiesti, S. Hariyani and F. R. Sutikno, "Pengelolaan Sampah Terpadu Berbasis Masyarakat Kota Kediri," Tata Kota dan Daerah, vol. 2, no. 2, pp. 95-102, 2010. 
[8] S. A. Yudistirani, L. Syaufina and S. Mulatsih, "Desain Sistem Pengelolaan Sampah Melalui Pemilahan Smapak Organik dan Organik Berdasarkan Presepsi Ibu-ibu Rumah Tangga," Konversi, vol. 4, no. 2, pp. 29-42, 2015.

[9] A. T. Hirzi, T. M. Umar, O. Hasbiansyah, D. Iskandar, H. Q. Hanifa and Y. Ariditha, "Sosialisasi dan Aplikasi Pengeloaan Sampah Organik di Desa Cikole Kecamatan Lembang Kabupaten Bandung Barat," in SNaPP2014, Bandung, 2014.

[10] S. Rijati, T. Intan and M. Subekti, "Sosialisasi Daur Ulang Sampah Sebagai Upaya Pengembangan Eko-Budaya di Lingkungan Desa Sayang Jatinangor Kabupaten Sumedang," Aplikasi Teknik dan Pengabdian Masyarakat, vol. 1, no. 2, pp. 29-34, 2017.

[11] L. Sulistyorini, "Pengelolaan Sampah Dengan Cara Menjadikan Kompos," Kesehatan Lingkungan, vol. 2, no. 1, pp. 77-84, 2005.

[12] U. B. Surono and Ismanto, "Pengolahan Sampah Plastik Jenis PP, PET dan PE Menjadi Bahan Bakar Minyak dan Karakteristiknya," Mekanika dan Sistem Termal, vol. 1, no. 1, pp. 32-37, 2016.

[13] R. Oktaria, H. R. Alwea and S. A. Utari, "Inovasi Pengelolaan Sampah Plastik Menjadi Bahan Bakar Minyak di Desa Jampang Bogor," in P2M Universtas Muhammadiyah Jakarta, Jakarta, 2019.

[14] S. S. Rahayu, A. Purnomo, V. S. Budiarti, Suharto and N. Hidayati, "Penerapan teknologi Tepat Guna Pengelolaan Sampah Berbasis Masyarakat Menuju Desa Mandiri Energi di Desa Banjarsari Kecamatan Gajah Kabupaten demak," in Hasil Pengabdian Kepada Masyarakat, Yogyakarta, 2019.

[15] F. L. Sahwan, D. H. Martono, S. Wahyono and L. A. Wiyosodarmono, "Sistem Pengelolaan Limbah Plastik di Indonesia," Teknologi dan Lingkungan, vol. 6, no. 1, pp. 311-318, 2005. 